\title{
Ensuring the level of interaction of stakeholders of construction enterprises with financial and economic security
}

\author{
$V$. Velychko ${ }^{1, *}, D$. Prunenko $^{1}, R$. Sheludko $^{2}, L$. Sheludko $^{2}$ \\ ${ }^{1}$ O.M. BeketovNationalUniversityofUrbanEconomy, MarshalaBazhanovaStreet, 17, 61000 Kharkiv, \\ Ukraine \\ ${ }^{2}$ Kharkiv National Agrarian University Named After V. V. Dokuchaiev, Dokuchaevske, 62483 \\ Kharkiv, Ukraine
}

\begin{abstract}
The tailing dump operation periodically leads to the failurThe article proves that modern economic conditions, which are characterized by instability of the socio-economic state, require improved approaches to the management of construction enterprises. The value of the factors, which determine the functioning of construction enterprises is increasing. The problem of ensuring financial and economic security in the system of interaction with stakeholders characterizes the modern aspects of their development. The importance of directions and peculiarities of stakeholder activity for the development of enterprises is determined. As a result of systematization of theoretical provisions, legal support and revealed features of functioning of construction enterprises, the types of stakeholders and indicators of the level of their interaction are determined. The ambiguity of changes in the formation and use of equity, cash and fulfillment of contractual obligations has been established. There is growth and focus on the quality of their implementation. The level of interaction of the studied construction enterprises with various groups of stakeholders is determined by the focus of considerable attention on ensuring relationships with customers. The measures affecting corporate relations to ensure financial and economic security of construction enterprises in the context of increasing the effectiveness of interaction with stakeholders are proposed.
\end{abstract}

\section{Introduction}

The modern economic conditions, which are characterized by instability of the socioeconomic state, require improved approaches to the management of construction enterprises. The value of the factors, which determine the functioning of construction enterprises is increasing. The problem of ensuring financial and economic security in the system of interaction with stakeholders characterizes the modern aspects of their development.

\footnotetext{
*Corresponding author: intplat2020@gmail.com
} 
The formation of financial and economic security to ensure interaction with stakeholders is affected by a significant number of important factors of construction enterprises, which form main directions of state. In international practice, considerable attention is paid to the directions and features of the activities of stakeholders. In particular, regulatory documents have been identified that ensure the process and areas of stakeholder interaction. In this context, it should be noted: Danish Civil Code (1907), Swiss Code of Obligations (1911), Normative legal documents on collective bargaining regulation of labor relations - Norway (1915), Germany (1918), Finland (1924), "Collective Bargaining. Convention" No. 154 (1981). In national practice, the National Standard of Ukraine "System of Social Responsibility Management", requirements of DSTU ISO / CD 26000: 2009, which directs the interaction of stakeholders with regard to the directions and peculiarities of the formation of social responsibility, has been adopted. Moreover, special attention is focused on increasing the satisfaction of interested parties. [1]. Therefore, security issues in collaboration with stakeholders is important and relevant. The purpose of the article is to develop measures to ensure the interaction of stakeholders of construction companies in the system of financial and economic security.

According to the aim, the following tasks were solved:

- identify and justify stakeholders interacting with construction enterprises;

- assess the level of interaction of construction enterprises with various groups of stakeholders.

In existing scientific developments, theoretical provisions are studied and substantiated to determine the stakeholders of enterprises. In particular, E. Freeman defines them as any group or individual that can influence, or which can be affected by the achievement of goals by an organization [2]. In this approach, the focus is on achieving the goal of the enterprise by ensuring interaction between stakeholders.

In contrast to the previous researcher P. Dunselmi characterizes stakeholders from the perspective of a functional approach and defines them as people or groups who are voluntarily or inadvertently exposed to the risk arising from the actions of the company [3]. Sharing the views of the presented approach, A. Ammari defines stakeholders as individuals or groups of individuals who are objects or subjects of the company's activities and policies at different management levels [4]. Note thatL. Gatsenko, while sharing the provisions of the functional approach, identifies problematic issues regarding the definition and interaction of stakeholders [5]. D. Cleland defines stakeholders as people or organizations or groups of people who have, or believe that they have legitimate claims to specific aspects of the project [6].

T. Donaldson and L. Preston focus on performance characteristics, which enable stakeholder engagement that identifies stakeholders from the perspective of identification directions through the actual or potential harm and benefit that they feel or expect to experience as a result of the company or omissions [7]. Moreover, the costs that ensure the interaction between stakeholders during the operation of enterprises are determined [8].

D. Andreev [9], P. Astakhov [10], T. Baums, T. Vasiltsiv [11], S. Goldman [12], D. Gorova [13], Eric M. [14], M. Jensen [15], E. Larsen [16], K. Mamonov [17], P. Markov [18], I. Otenko [19], etc. are focusing on ensuring financial and economic security. Along with a large number of scientific developments on the problems of interaction between stakeholders, the formation of financial and economic security, questions regarding their integrated application at construction enterprises remain unresolved.

\section{Materials and methods}

Stakeholders have a significant influence on the functioning of construction enterprises, ensuring their financial and economic security. The following groups of stakeholders 
interacting with construction enterprises are identified in scientific developments (Table 1). Depending on their involvement in the investment and construction process, some authors identify the following stakeholder groups: direct participation: investors, developers, banking institutions, customers, contractors, designers;

indirect participation: market infrastructure participants, public administration and supervisory services, public organizations, mass media, consumers of construction products, owners of adjacent territories, competitors [21, p. 123-124]. N. Petrishenko subdivides stakeholders in the construction sector into:

- internal (staff, shareholders, investors);

- external (population, governing bodies, institutions and organizations that affect the management of the sector) [22].

Table 1. Stakeholder groups interacting with construction enterprises [20]

\begin{tabular}{|c|c|}
\hline $\begin{array}{c}\text { Stakeholder groups } \\
\text { Investors of construction } \\
\text { enterprises }\end{array}$ & Stakeholders \\
\hline $\begin{array}{c}\text { Managers of different } \\
\text { levels }\end{array}$ & $\begin{array}{c}\text { company owners, top managers, heads of divisions, heads of } \\
\text { departments, heads of other organizational structures. }\end{array}$ \\
\hline $\begin{array}{c}\text { Staff of construction } \\
\text { enterprises }\end{array}$ & $\begin{array}{c}\text { personnel providing enterprise management, production personnel, } \\
\text { marketing personnel, warehouse staff, other personnel involved in } \\
\text { production and economic activities. }\end{array}$ \\
\hline $\begin{array}{c}\text { Partners of construction } \\
\text { enterprises }\end{array}$ & $\begin{array}{c}\text { material suppliers, dealers, consumers. } \\
\text { Social (social group) }\end{array}$ \\
\hline $\begin{array}{c}\text { Non-governmental organizations, non-governmental foundations, } \\
\text { human rights defenders, public control bodies, trade union } \\
\text { organizations, and other social groups. }\end{array}$ \\
\hline Public administration & $\begin{array}{c}\text { central public administration, regional public administration, local } \\
\text { self-government bodies, fiscal authorities, other public } \\
\text { administration bodies. }\end{array}$ \\
\hline
\end{tabular}

A. Hutsalo, in the context of the definition of stakeholders, focuses on contractors, taking into account functional, product, economic and administrative-structural features [23]. Among the stakeholders in the construction sector, special attention is paid to selfregulatory organizations. The importance of their formation and maintenance of functioning is indicated by scientists: O. Nepomnyashchy [24], V. Suslov [25], N. Slyusarevsky [26], O. Stukalenko [27].

Note that at the legislative level, the powers of self-regulatory organizations are defined. In particular, the Law of Ukraine "On Architectural Activities" stipulates that selfregulatory organizations are non-profit voluntary associations of individuals and legal entities in the relevant area of entrepreneurial or professional activity that have received appropriate status in the established manner [28].

For the creation and development of self-regulatory organizations in the construction 
sector, regulatory support is applied: On approval of the Procedure of delegation of powers to self-regulatory organizations in the field of architectural activity [29], On approval of the procedure for registration of self-regulatory organizations in the field of architectural activities [30], On registration of Ukrainian public organization "Association of experts of the construction industry"as a self-regulatory organization in the field of architectural activity and entry of information about it in the relevant state register [31], On delegation of powers of the Ministry of Regional Development for conducting professional certification of experts to the self-regulatory organization in the field of architectural activity Ukrainian public organization Association for the construction industry experts [32]. The following groups of stakeholders, interacting in the construction sector, were identified following the preliminary analysis of the scientific sources of the authors, who devoted their work to this topic, accumulating different approaches to the following grouping:

- managers of different levels;

- owners of construction companies;

- workers of construction enterprises;

- shareholders;

- internal control bodies;

- external controlling bodies;

- credit and other financial institutions, developers;

- public administration bodies;

- local authorities;

- customers and investors;

- developers and contractors;

- designers;

- suppliers of inventory for the work of construction enterprises;

- public and self-regulatory organizations operating in the construction sector;

- organizations and companies providing information support for the functioning of construction enterprises.

As a result of the systematization of theoretical provisions, regulatory legal support and revealed features of functioning of construction enterprises, the types of stakeholders and indicators of the level of their interaction are determined:

1. Customers $\left(S_{21}\right)$.

2. State authorities $\left(S_{22}\right)$.

3. Public and trade union organizations in construction and architecture $\left(S_{23}\right)$.

4. Contractors $\left(S_{24}\right)$.

5. External controlling bodies impact on the functioning of the construction companies $\left(S_{25}\right)$.

6. The internal controls over the operation of construction companies $\left(S_{26}\right)$.

7. Owners of construction enterprises $\left(S_{27}\right)$.

8. Managers of construction enterprises at various levels $\left(S_{28}\right)$.

9. Workers $\left(S_{29}\right)$.

10. Financial and banking institutions $\left(S_{210}\right)$.

11. Competitors - other construction enterprises $\left(S_{211}\right)$.

12. Design enterprises and organizations $\left(S_{212}\right)$.

13. Mass media and other organizations providing information support to the activities of construction enterprises and the construction market $\left(S_{213}\right)$.

14. Other enterprises and organizations $\left(S_{214}\right)$.

The characteristic values of the indicators of interaction between construction enterprises and various groups of stakeholders interacting with them are represented by a scale of values that range from 0 to 10 . 
The results of assessing the level of interaction of the studied construction enterprises with various groups of stakeholders by the method of expert evaluations are presented in Table. 2.

Table 2. Results of assessing the level of interaction of construction enterprises with various groups of stakeholders, rel. units

\begin{tabular}{|c|c|c|c|c|c|c|c|c|c|c|c|c|c|c|}
\hline $\begin{array}{l}\text { Types of } \\
\text { stakehold } \\
\text { ers }\end{array}$ & $\begin{array}{l}S \\
21\end{array}$ & $S_{22}$ & $S_{23}$ & $S_{24}$ & $S_{25}$ & $S_{26}$ & $S_{27}$ & $S_{28}$ & $S_{29}$ & $S_{210}$ & $S_{211}$ & $S_{212}$ & $\begin{array}{l}S_{2} \\
13\end{array}$ & $\begin{array}{c}S_{2} \\
14\end{array}$ \\
\hline \multicolumn{15}{|c|}{ JSC "HC" Kyivmiskbud " } \\
\hline $\begin{array}{c}\text { Average } \\
\text { value }\end{array}$ & $\begin{array}{l}7 . \\
9\end{array}$ & 7.7 & 4.9 & 7.6 & 4.9 & 7.4 & 7.4 & 7.5 & 5.5 & 4.8 & 4.1 & 7.5 & $\begin{array}{l}4 . \\
2\end{array}$ & $\begin{array}{l}3 . \\
2\end{array}$ \\
\hline \multicolumn{15}{|c|}{ OJSC «Brovarsky Plant of Structural Structures» } \\
\hline $\begin{array}{c}\text { Average } \\
\text { value }\end{array}$ & $\begin{array}{l}5 . \\
3\end{array}$ & 2.9 & 3.2 & 4.4 & 3.2 & 5.1 & 4.7 & 5.0 & 3.3 & 2.8 & 2.9 & 5.2 & $\begin{array}{l}2 . \\
8\end{array}$ & $\begin{array}{l}2 . \\
3\end{array}$ \\
\hline \multicolumn{15}{|c|}{ JSC "KGBC" } \\
\hline $\begin{array}{c}\text { Average } \\
\text { value }\end{array}$ & $\begin{array}{l}4 . \\
7\end{array}$ & 2.9 & 2.9 & 4.2 & 3.0 & 4.7 & 4.1 & 4.4 & 2.9 & 2.5 & 2.7 & 4.3 & $\begin{array}{l}2 . \\
4\end{array}$ & $\begin{array}{l}2 . \\
0\end{array}$ \\
\hline \multicolumn{15}{|c|}{ JSC "Trust Zhitlobud - 1" } \\
\hline $\begin{array}{c}\text { Average } \\
\text { value }\end{array}$ & $\begin{array}{l}6 . \\
7 \\
\end{array}$ & 6.6 & 4.7 & 4.5 & 4.3 & 5.3 & 4.1 & 4.4 & 3.4 & 2.7 & 3.3 & 4.6 & $\begin{array}{l}2 . \\
9 \\
\end{array}$ & $\begin{array}{l}2 . \\
1 \\
\end{array}$ \\
\hline \multicolumn{15}{|c|}{ LLC Construction Company «Miskzhitlobud» } \\
\hline $\begin{array}{c}\text { Average } \\
\text { value }\end{array}$ & $\begin{array}{l}4 . \\
2\end{array}$ & 2.8 & 2.8 & 3.7 & 2.7 & 4.3 & 3.9 & 3.7 & 2.7 & 2.5 & 2.4 & 3.9 & $\begin{array}{l}2 . \\
3\end{array}$ & $\begin{array}{l}2 . \\
1\end{array}$ \\
\hline \multicolumn{15}{|c|}{ PJSC "Capital Real Estate" } \\
\hline $\begin{array}{l}\text { Average } \\
\text { value }\end{array}$ & $\begin{array}{l}4 . \\
1\end{array}$ & 2.9 & 2.9 & 3.7 & 2.9 & 4.4 & 3.9 & 3.5 & 2.8 & 6.0 & 2.3 & 3.9 & $\begin{array}{l}2 . \\
5\end{array}$ & $\begin{array}{l}2 . \\
3\end{array}$ \\
\hline \multicolumn{15}{|c|}{ 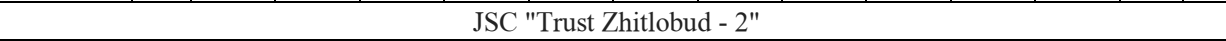 } \\
\hline $\begin{array}{c}\text { Average } \\
\text { value }\end{array}$ & $\begin{array}{l}3 . \\
9 \\
\end{array}$ & 2.7 & 2.7 & 3.2 & 2.8 & 4.3 & 3.8 & 3.3 & 2.9 & 2.3 & 2.1 & 3.1 & $\begin{array}{l}2 . \\
4 \\
\end{array}$ & $\begin{array}{l}2 . \\
2 \\
\end{array}$ \\
\hline \multicolumn{15}{|c|}{ Ukrainian State Building Corporation "UkrBud" } \\
\hline $\begin{array}{c}\text { Average } \\
\text { value }\end{array}$ & $\begin{array}{l}5 . \\
8\end{array}$ & 4.8 & 3.3 & 3.1 & 2.8 & 4.5 & 4.1 & 3.5 & 2.8 & 5.9 & 2.4 & 3.0 & $\begin{array}{l}2 . \\
6 \\
\end{array}$ & $\begin{array}{l}2 . \\
4\end{array}$ \\
\hline \multicolumn{15}{|c|}{ Construction group "Fundament" } \\
\hline $\begin{array}{c}\text { Average } \\
\text { value }\end{array}$ & $\begin{array}{l}3 . \\
6\end{array}$ & 2.5 & 2.6 & 3.2 & 2.5 & 3.5 & 3.8 & 3.1 & 2.8 & 2.4 & 2.4 & 2.7 & $\begin{array}{l}2 . \\
6\end{array}$ & $\begin{array}{l}2 . \\
5\end{array}$ \\
\hline
\end{tabular}

As a result of the study, an analysis of the state and characteristics of the interaction of stakeholders with the studied construction enterprises was performed. The ambiguity of changes in the formation and use of equity, cash, the fulfillment of contractual obligations is determined. Along with a low level of implementation, there is an increase and focus on the quality of their implementation. The level of interaction of the studied construction enterprises with various groups of stakeholders is determined by the focus of considerable attention on ensuring relationships with customers.

Under such conditions, the implementation of financial and economic security measures to increase the effectiveness of interaction with stakeholders is of particular importance. Particularly important is the development and implementation of corporate relationships through:

- increasing the effectiveness of cooperation with anti-corruption bodies;

- implementation of the current legislation in terms of opportunities for corruption, conflicts of interest;

- continuous monitoring and control over the movement of fixed and current assets, the formation and use of own and borrowed funds;

- improvement of the corporate governance system, ensuring interaction between corporate bodies; 
- detection of violations of current legislation and failure to fulfill contractual obligations;

- the widespread use of property protection instruments;

- the development and implementation of an effective mechanism for ensuring financial and economic security;

- increasing the level of information security;

- ensuring compliance of valuation of assets of enterprises with their market value.

- Of particular importance are the activities on:

- increase of profitability of functioning of companies, ensuring excess of income over expenses;

- creating opportunities for repayment of current liabilities with its current assets;

- increase in the share of cash in the general structure of assets of construction enterprises;

- increase in the proportion of equity in the overall structure of financing sources compared to the proportion of borrowed funds;

- ensure the efficient use of assets and other noncurrent assets;

- increased efficiency in the use of current assets elements of construction enterprises;

- ensuring the established high level of labor productivity in the formation of a permanent professional "core" of working capital.

\section{Conclusions}

As a result of the study, stakeholders interacting with construction enterprises were identified, the level of relationships was determined. Their ambiguity and contradictions are established, which requires the development and implementation of measures to ensure financial and economic security.

To ensure the level of interaction with stakeholders, measures for the formation and implementation of financial and economic security are proposed: increasing the quality of corporate governance and the effectiveness of relationships with various groups of stakeholders, active use of corporate and anti-raider codes, ensuring interaction between corporate governance bodies, the formation of the economic security system at all levels of production and economic activity, the attraction of skilled workers, creation of conditions for strengthening of financial and economic condition, an increase of social responsibility of construction enterprises, timely detection of raid attacks and influence on them.

\section{References}

1. National Standard of Ukraine "Social Responsibility Management System", requirements of DSTU ISO / CD 26000: 2009. State Consumer Standard of Ukraine, (2009), http://online.budstandart.com/

2. E. Freeman,Strategic Management: A Stakeholder Approach, Pitman, Boston, 34 (1984)

3. P. D'Anselmi, «Values and Stakeholders in an Era of Social Responsibility», Free Press, New York, NY, 27 (2011)

4. A.O. Ammari, Act. Probl. Econ.: Sci. Econ. J., 8, 150 (2012)

5. L. Gatsenko, Stakeholder theories: history of development and problem questions for further research, https://www.google.com/ 
6. D. Cleland, Project Stakeholder Management, 1 (2004)

7. T. Donaldson, L. Preston, Academy of Management Review, 1, 65 (1997)

8. L. Preston, Corporate Governance: an International Review, 11 (3), 151 (2004)

9. D.O. Andreev, Administrative and legal means of protection of the rights of the owners of securities (2008)

10. P.A. Astakhov, Counteraction to raider seizures (2007)

11. T.G. Vasyltsiv, R.M. Mykytuk, Improvement of method of estimation of economic security of enterprise, https://nv.nltu.edu.ua/

12. Sachs Goldman, The Practice of Risk Management, 284 (1996)

13. D.A. Gorovy, V.Yu. Nesterenko., Bulletin of the National Technical University "Kharkiv Polytechnic Institute": collection of scientific papers. Thematic Issue: Technical progress and production efficiency, 5, 26 (2009)

14. M. Eric, Uslanner, Corruption, inequality and the rule of law, 344 (2008)

15. M. Jensen, J. of Financial Economics, 11, 5 (1983)

16. E. Larsen, The rise of the e-citizen. How people use government agencies, http://www.pewinternet.org

17. K.A. Mamonov, O.V. Pirkova, Y. Jiangbo, Crimean Economic Bulletin, 4, 118 (2013)

18. P. A. Markov, Friendly absorption. Law and Economics, 10, 15 (2008)

19. I.P. Otenko, G.A.,Ivashchenko, D.K. Voronkov, Economic Security of the Enterprise, Kharkov: KhNEU Publishing House (2012)

20. K.A. Mamonov, Stakeholder strategy for value-oriented brand management of construction corporate enterprises: ScD dissertation (2013)

21. I.B. Azarova, Value-oriented approach in the management of housing investment projects. PhD thesis(2015)

22. N.A. Petryshchenko Analysis of construction in regions of Ukraine, Scientific discussion 192, https://economics.opu.ua/

23. A.V. Gutsalo, Economic-managerial reengineering of business processes of a contractor: PhD thesis (Economics), Kyiv National University of Civil Engineering and Architecture (2017)

24. A. Nepomnyashchiy, Decentralization of public construction activity regulation: world experience for Ukraine (2014), http://www.kbuapa.kharkov.ua/

25. V.V. Suslova, The bulletin of YaroslavMudryi national law universit, 4, 122 (2011)

26. N. Slyusarevsky, Mirror of the week: international socio-political weekly, 36, 6 (2010)

27. O. Stukalenko, Journal of the South Regional Center of National Academy of Legal Sciences of Ukraine, 7, 159 (2016)

28. On Architectural Activity. Law of Ukraine No. 687-XIV of May 20, (1999) http://zakon4.rada.gov.ua/

29. On approval of the Procedure of delegation of powers to self-regulatory organizations in the field of architectural activity: Order of the Ministry of Regional Development, Construction and Housing and Communal Services of Ukraine, http://zakon5.rada.gov.ua/

30. On approval of the Procedure for registration of self-regulatory organizations in the field of architectural activity: Order of the Ministry of Regional Development of Ukraine from 13.05.2014, 137, http://zakon4.rada.gov.ua/ 
31. On the registration of the All-Ukrainian public organization "Association of experts of the construction industry" as a self-regulatory organization in the field of architectural activity and entering information about it in the relevant state register: Order of the Ministry of Regional Development of 06.08.2014, 217, http://online.budstandart.com/

32. On delegation of powers of the Ministry of Regional Development for conducting professional certification of experts to the self-regulatory organization in the field of architectural activity - All-Ukrainian public organization Association of experts of the construction industry: Order of the Ministry of Regional Development of 16.06.2015, 138, http://online.budstandart.com/ 